Article

\title{
The Changing Structure and Concentration of Agricultural Land Holdings in Estonia and Possible Threat for Rural Areas
}

\author{
Evelin Jürgenson * and Marii Rasva
}

Chair of Geomatics, Institute of Forestry and Rural Engineering, Estonian University of Life Sciences, Kreutzwaldi 5, 51014 Tartu, Estonia; marii.rasva@emu.ee

* Correspondence: Evelin.Jyrgenson@emu.ee; Tel.: +372-505-7428

Received: 5 January 2020; Accepted: 31 January 2020; Published: 2 February 2020

\begin{abstract}
In most European countries, there has been a decrease in the number of farms, while the area of agricultural land has remained almost the same. This ongoing process of land concentration can affect Europe's small farms and rural areas. The EU has acknowledged that the problem is serious and that, to solve it, it must be studied more closely. Accordingly, the aim of this study is to discuss changes in the agricultural sector from the aspect of land use, with emphasis on land concentration in Estonia, further scientific discussion about the effects of changes in land use on rural areas is encouraged. The study is carried out using two kinds of data sources: (1) statistical data from Eurostat, FAOSTAT and Statistics Estonia, (2) data from the Estonian Agricultural Registers and Information Board. The conclusion of the paper is that while the number of farms is going down, the average area of agricultural land use per farm is on the rise in Estonia. Agricultural land has been increasingly concentrated into the hands of corporate bodies. This study shows that there is a status of land concentration in Estonia that needs ongoing studies and a proper policy should be established to mitigate the impact of land concentration.
\end{abstract}

Keywords: agricultural land use; land concentration; landholding; Estonia

\section{Introduction}

\subsection{Motivation}

The agricultural sector is directly connected to the issue of food security. Land, an elemental source for the production is needed. It is scarce resource, not a "normal" market good [1] and therefore land issues may require special regulations.

The rush for land in developing countries in the Global South has caught much attention, much less has been given to the process of land concentration in Europe [2-4]. Large agricultural land users in Europe are expanding their scope widely and quickly. Tens of thousands of small farmers are being forced out of farming every year [4,5]. It is also evident that in many European countries, the degree of land-based inequality is similar to some countries with notoriously inequitable distribution of land ownership and land-based wealth such as Brazil, Colombia, and the Philippines [4,6].

A report in the European Union [7] points out that the ongoing process of farmland concentration in Europe is just as problematic as farmland grabbing. As land becomes concentrated into fewer and larger holdings, the Common Agricultural Policy (CAP) subsidy becomes more concentrated as well [4]. Although the EU considers land concentration to be a serious issue, there have been few current studies. Additional country-specific research is also needed. The present study is mainly focused on the problem of land concentration, referring to a process in which large agricultural producers are increasingly buying up or leasing land from other agricultural producers. 
The ongoing process of land concentration has particularly affected Europe's small farms: it is implied that the expansion of large farms in Europe has come at the expense of small farms [7]. Agricultural land is becoming increasingly concentrated into the hands of large businesses, a situation in which small farmers are losing control of their land $[7,8]$. In the meantime, small farms are important for rural life: they play an active role in the economic fabric of rural areas, conserving the cultural heritage, maintaining rural life, sustaining social life and making sustainable use of natural resources. Small farms produce a sufficient amount of healthy and high-quality food and ensure a broad distribution of land ownership in rural areas [6,8-13]. In short, the process of land concentration has implications for society as a whole, not only for small farms.

There is no universally accepted definition of small or large farms [3,14]. The farms may be divided according to different parameters, such as farm structural size, economic size, herd size, labour force or utilised agricultural area $[3,11]$. There are many discussions about the relative productivity of large or small agricultural producers in light of the growing world population. Economic efficiency and productivity depend on many criteria. It is frequently stated that purely economic results are better for the larger farms. Even the negative impact caused by land fragmentation can be negated by the larger utilised land area [15]. At the same time, large farms can be inefficient due to the high monitoring cost, anonymity and lack of transparency [16]. However, the larger picture should include not just economic factors, but, for example, the social impacts as well.

\subsection{Historical Overview of Changes in the Agricultural Sector in Estonia}

Agriculture in Estonia has been through many changes, caused by different policies. Before Estonian independence in 1918 agricultural land in Estonia was owned by Baltic Germans. After gaining independence, this situation changed. There were numerous assumptions for triggering land reform. Before the reform, $58 \%$ of agricultural land was used by large agricultural holdings [17-19]. To carry out the land reform the majority of agricultural land owned by estate owners was expropriated by the state. As a result of this reform, ca 140,000 farms with an area over 1 ha were created, the previous number was 50,000 farms $[17,20]$.

In 1940, the Soviet Union occupied Estonia and land was declared as people's property [20,21]. The largest land area that one working peasant could own was 30 ha. The rest of the land was incorporated into the State's land fund or given out to those peasants who had too small an area of land for agricultural use [20,22]. In the summer of 1941, Germany occupied Estonia and another change in agriculture followed: changes made by the Soviet Union were cancelled and the land divided during the land reform was given back to its rightful owners [20]. After three years of German occupation, the Soviet Union occupied Estonia and the declaration of 1940 was restored [21]. The state became the landowner and collectivization took place, simply as a political decision. It was believed that large agricultural holdings like kolkhozes and sovkhozes were more efficient than small farms. Forced collectivization intensification took place in 1949 when kolkhozes and sovkhozes were merged into larger ones.

The average area of kolkhozes and sovkhozes changed over the years, with the kolkhozes tending to be smaller than sovkhozes. By 1976, their average area was equalised. The total area of kolkhozes was 8086 ha, containing 4333 ha agricultural land. The total area of sovkhozes was 8015 ha, with 4542 ha agricultural land [20,23]. The optimal size of kolkhozes and sovkhozes was a research issue in the Soviet time. According to the instructions from the 1960s, the optimal area for kolkhozes and sovkhozes in Estonia would be 5500-9000 ha, that includes agricultural land 4500-6,500 ha and again arable land 1700-1900 ha [23,24]. By the year 1980 kolkhozes and sovkhozes had grown into giants and had to be divided into smaller ones $[17,23]$.

Before independence was restored in Estonia, the Estonian SSR Farm Act was instituted in 1989, with benefit to small agricultural businesses. It didn't restore private property but it made private agricultural farming legal: 10,152 farms received the right to use 252,255 ha land $[18,20,25]$. 
As Estonian independence was restored in 1991, new winds started to blow in agriculture. Firstly, there was a goal to restore ownership of former farms. It was important to support agricultural land use that was based on small farms. To redesign ownerships based on historical, economic policy and socio-psychological subjects, it was also decided to enforce land reform $[18,20,25]$. The land reform law and then the agriculture reform law both favoured agriculture based on small farms $[18,23]$. Many small agricultural users arose in Estonia but as the years went by this number decreased.

Land reform in Estonia has had a combination of aims: to raise economic efficiency, the need to move to a market economy, and to repair historical injustice to owners whose real properties had been expropriated [25]. The same has been true in other Central and Eastern European countries that implemented land reform [26-28]. The multiple aims had a side effect-land fragmentation-in Estonia and other Central and Eastern European countries that implemented land reform [29-32]. As a result, some of the countries (for instance, Lithuania, Poland) that implemented land reform recently have developed the strategy of land consolidation [29,30], a strategy which has not taken hold in Estonia $[25,29]$. However, agricultural land holdings have enlarged over the years. The agricultural producers acquire available land plots that are situated at a distance from the farming centre and previous land plots. Maasikamäe et al. [33] presented that issue based on the polygons drawn over each agricultural land producer's land plots. Usually, several polygons (several agricultural producers' land holdings) overlap each other. It means workers must move from plot to plot, and sometimes these land plots are at a distance. The Estonian agricultural production situation is different from the eastern European Member States (Czech Republic, Slovakia) which implemented the land reform but went over to corporate farms [9,30]. Although administrations have changed, land use has remained more or less the same.

However, since the restoration of the Republic of Estonia in 1991, there has been considerable development. The centrally-planned economy has moved to a free-market basis. Currently, property and land reform has been almost entirely implemented. The land reform has changed the previous land relations: issues between state and private ownership have been resolved [25]. The property and land reform have led to changes in the agricultural sector as well: the kolkhozes and sovkhozes have been replaced with private agricultural producers. At the beginning of the reforms it was expected that a private small farm system would take over the system of kolkhozes and sovkhozes [20,23], but the trend did not continue: the number of small farms has decreased and continues to do so.

\subsection{Aim and Scope}

In 2014, the problem of land grabbing and land concentration was brought up by the European Economic and Social Committee. The European Economic and Social Committee decided to draw up its own-initiative opinion on "Land grabbing — a warning for Europe and a threat to family farming (own-initiative opinion)". This document was adopted in January 2015 [8]. It makes clear that since land forms the basis of food production, there is an obligation for countries to recognise the right of each individual living in their own territory to adequate and safe food, that is directly linked to access to land. As land is no ordinary commodity and its supply is finite, it will be necessary to regulate the market for agricultural land and to prevent land concentration. Accordingly, there must be greater regulations on land use and ownership. It is also important to adjust the CAP so that the first few hectares can be given a stronger weighting in direct payments. This could strengthen small farms and increase their ability to compete, thus the usual market rules should not apply.

Following that European and Economic and Social Committee document [8], the European Parliament's Committee on Agriculture and Rural Development requested the study "Extent of farmland grabbing in the EU", which was published in May 2015 [7]. In 2017, the European Parliament reported on "The state of play of farmland concentration in the EU: how to facilitate the access to land for farmers?" [6]. It points out that land, its management, and urban development rules are matters for the Member States, better account should be taken of farmland conservation and management. The report also called on the Member States to focus their land-use policies on using available tools 
(taxation, aid schemes and CAP funding) to maintain a family-farm-based agricultural model. The land policy must help to ensure broad, fair and equitable distribution of land tenure and access to land.

There are different rules for the independent governing of EU Member States' land-use policies and those for the agricultural land market. The European Association for Rural Development Institutions (AEIAR) reported in 2015 on the status of agricultural land market regulation in seven European countries (Germany, Belgium, France, Hungary, Italy, Lithuania, and Poland) [34]. The report states that all addressed countries use the tools for regulations of the agricultural land market and some use the approval process. For example, in Germany, sales of agricultural land over a certain size must be approved by the administrative authority. In France, there is special private, non-profit organization SAFER that is responsible for observing land transactions, setting up and restructuring agricultural and forestry structures, supporting local development and contributing to the protection of the environment. In Hungary, the notary sends the relative documents to the agricultural administrative authority for approval of a sale. All countries in the report are allowed to use the pre-emption right if agricultural land is sold. Some countries have limits for land ownership: 500 hectares in Lithuania and 300 hectares in Hungary. Additionally, Hungary limits land possession to 1200 hectares (consisting of owned and leased land).

In addition to the concentration of land, there are several other drivers-technological, institutional, and economical-which when combined, can influence changes in the pattern of agricultural land use [35]. For example, land needed for dwellings, infrastructure and commerce has decreased the total area of agricultural land. Such changes can alter rural societies in ways that can be a threat in sparsely populated areas. All these disruptions, though not the focus of this paper, are still relevant when considering the current and future status of land use.

This paper presents the statistical data about the changes in agricultural land use and a number of producers in the European Union, giving primary attention to the changes in Estonian agricultural producers' land holdings up till 2016. The bases for analyses are the landholdings (owned or leased) area per agricultural producers. The aim of the paper is to discuss changes in the agricultural sector from the aspect of land use, with the emphasis on land concentration in Estonia, and to encourage scientific discussion about the effects of changes in agricultural land use on rural areas in Europe, using the example of changes in Estonian agricultural producers' land holdings following the property and land reform that started in 1991 in Estonia. As Estonia is a small country, the changes take place more quickly and within a shorter time frame than in larger countries. Therefore, the Estonian case can be helpful to other countries as it helps to understand the changes in other European countries as well. This paper presents the first in-depth study of the agricultural land use and holdings changes following the property and land reform that started in 1991 in Estonia.

\section{Materials and Methods}

Two kinds of data sources were needed for the study. The first was statistical data from Eurostat, FAOSTAT and Statistics Estonia, the second considered the data for the landholdings of agricultural producers. This information source is the Estonian Agricultural Registers and Information Board (ARIB).

Data from Eurostat (https://ec.europa.eu/eurostat/) is used to compose the overview of agricultural land use in European countries, including data about utilised agricultural land use, the number of farms and average utilised agricultural land area per farm. The Eurostat data is from the years 2005, 2007, 2013 and 2016. However, the figures mainly present the changes between the years 2005 and 2016. In two cases (Croatia, Italy) the data was incomplete and data from 2007 or 2013 had to be used. The year 2016 or 2013 was used as the base year for calculating the changes that took place in the area of utilised agricultural area, number of farms and average utilised agricultural land area per farm. Eurostat's mission is to provide high-quality statistics for Europe.

Eurostat defines utilised agricultural land as follows:"Utilised agricultural area, abbreviated as UAA, is the total area taken up by arable land, permanent grassland, permanent crops and kitchen gardens used by the holding, regardless of the type of tenure or of whether it is used as a part of 
common land". Farm is defined as a single unit, both technically and economically, operating under single management and which undertakes agricultural activities within the economic territory of the European Union, either as its primary or secondary activity. Other supplementary (non-agricultural) products and services may also be provided by the holding.

Data from FAOSTAT (http://www.fao.org/faostat/en/\#data) is also used in this study to provide an overview of agricultural land use in European countries. The FAOSTAT data is from years 2005 and 2016. The base year for calculating the changes in the area of agricultural land was 2016. It was necessary to add FAOSTAT data to this study because it differs a bit from Eurostat data about the utilised agricultural land area. FAOSTAT defines the agricultural land area as land used for the cultivation of crops and animal husbandry. The total of these areas falls under "Cropland" and "Permanent meadows and pastures".

Statistics Estonia (https://www.stat.ee/about) defines an agricultural household as a unit with uniform technical and economical management and at least one hectare of agricultural land, or where agricultural products are produced primarily for sale (irrespective of land area). From 2007, agricultural households are also units where agricultural products are not produced but the land is being conserved in good agricultural and environmental conditions. Agricultural land area in use is land that is used for agricultural production or being conserved in good agricultural and environmental conditions by agricultural households in the reference year.

ARIB data (ARIB is responsible for delivery of national and the EU subsidies for agricultural activities) from 2011 and 2016 is used for the case study to present a more detailed overview of the recent changes in the pattern of agricultural landholdings in Estonia. Figure 1 illustrates the study area and its location in Europe.

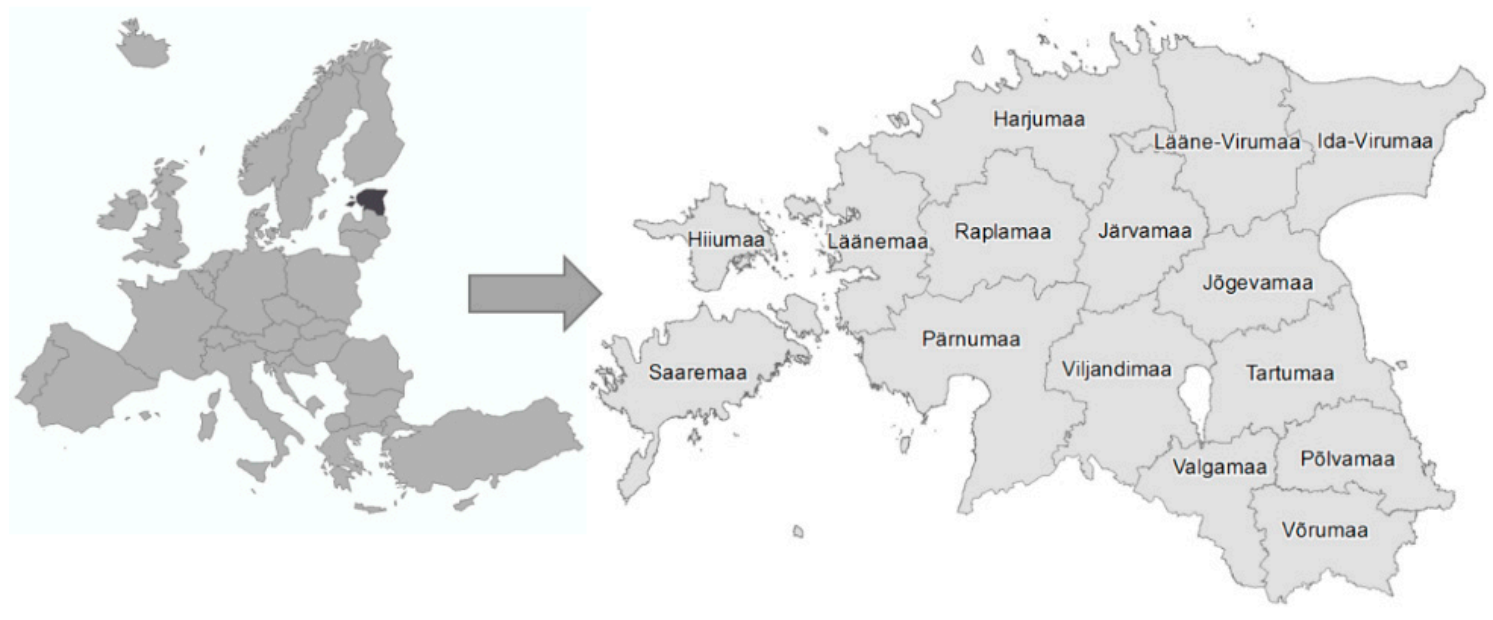

Figure 1. Location of Estonia (study area) in Europe.

The data from the ARIB Field Register is used for the study. The Field Register is one of three registers in the charge of ARIB and area support is one of the subsidies that ARIB delivers. The digitalised database of agricultural plots is required for payment of area support from the budget of the EU. In the process of delivering national and EU subsidies, ARIB collects information about the applicant (every applicant gets an ID number) and land that is filed for area support.

ARIB data about the agricultural land area and the number of producers were analysed in order to get an overview of changes in Estonian agricultural land users' landholdings. Agricultural land users and land area per producer was summarized using GIS software ArcGIS (version 10.4). Producers were divided into six groups according to the size of their landholdings: $0-<2$ ha, $2-<40$ ha, $40-<100$ ha, $100-<400$ ha, $400-<1000$ ha and $>1000$ ha, data was taken on the basis of these size groups. The basis for this division comes from Farm Accountancy Data Network (FADN) (https: $/ /$ maainfo.ee/index.php?page=9\&) where agricultural land area is divided into four size groups 
(0-<40 ha, 40-<100 ha, 100-<400 ha, $>400$ ha). In order to get a closer look at the smallest agricultural land users, FADN size group $0-<40$ ha was divided into size groups $0-<2$ ha and $2-<40$ ha. FADN size group $>400$ ha was divided into size groups $400-<1000$ and $>1000$ ha in order to characterise the largest agricultural land users.

This study concentrates on agricultural land users' land holdings that cover all plots which are used for agricultural production in Estonia. No distinction is made between land held in ownership and leasehold land. Also, no differentiation was made between different production groups.

\section{Results}

\subsection{Agricultural Land Use Pattern and Its Changes in Europe}

Europe has 12 million agricultural land users, with 25 million people involved in agricultural production and $69 \%$ of agricultural land users having less than five hectares: the average size is 14.2 ha [36]. The total number of agricultural land users in the Baltic and Nordic countries is 607,500, which is $4.2 \%$ of the total number in the EU. In 2009, the agricultural land user had an average 59.7 ha of the agricultural area in Denmark, 42.9 ha in Sweden, 38.9 in Estonia, 33.6 ha in Finland, 16.5 ha in Latvia and 11.5 ha in Lithuania [37].

According to Eurostat, between 2005 and 2016 (Figure 2), the utilised agricultural land area has grown in Bulgaria, Estonia, Ireland, Greece, Croatia, Latvia, Lithuania, Luxembourg, Hungary, Malta, Slovenia, Slovakia and the United Kingdom. The agricultural land area has decreased in other European countries, in greater quantity in Germany, Spain, Romania and Switzerland.

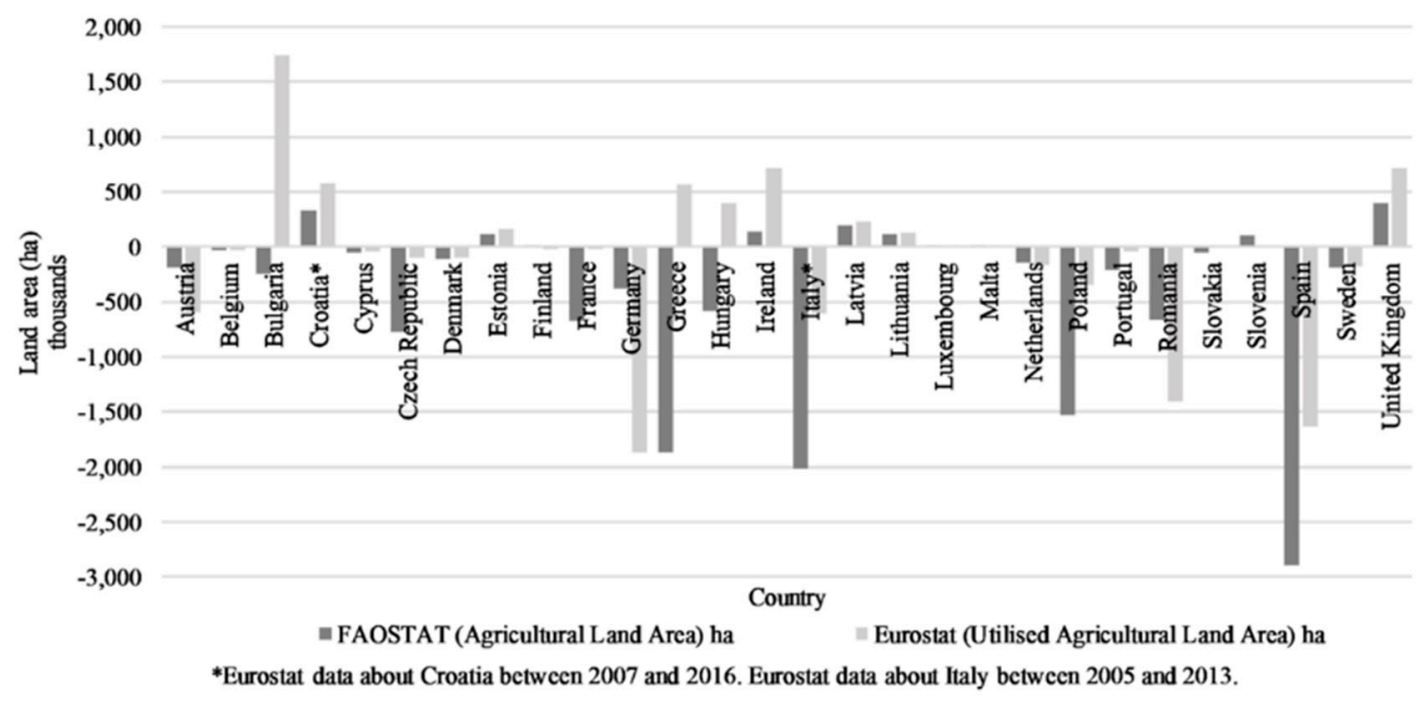

Figure 2. Utilised agricultural land (Eurostat) and agricultural land (FAOSTAT) use change (ha) in Europe between 2005 and 2016.

FAOSTAT data shows that, unlike Eurostat data, utilised agricultural land area has decreased in Bulgaria, Greece and Hungary. These indicators are more similar in other countries. Utilised agricultural land and agricultural land are not precisely the same concepts and their collecting methodology differs, therefore further study is needed regarding the differences seen in Figure 2.

The total number of farms in Europe between 2005 and 2016 (Figure 3) has decreased by four million, affecting all countries except for Ireland, where there was an increase of 4860 farms. The largest $(-1,065,770)$ decrease in the number of farms has occurred in Poland, but the decrease is remarkable in Romania $(-834,120)$ and Italy $(-718,200)$ as well. 


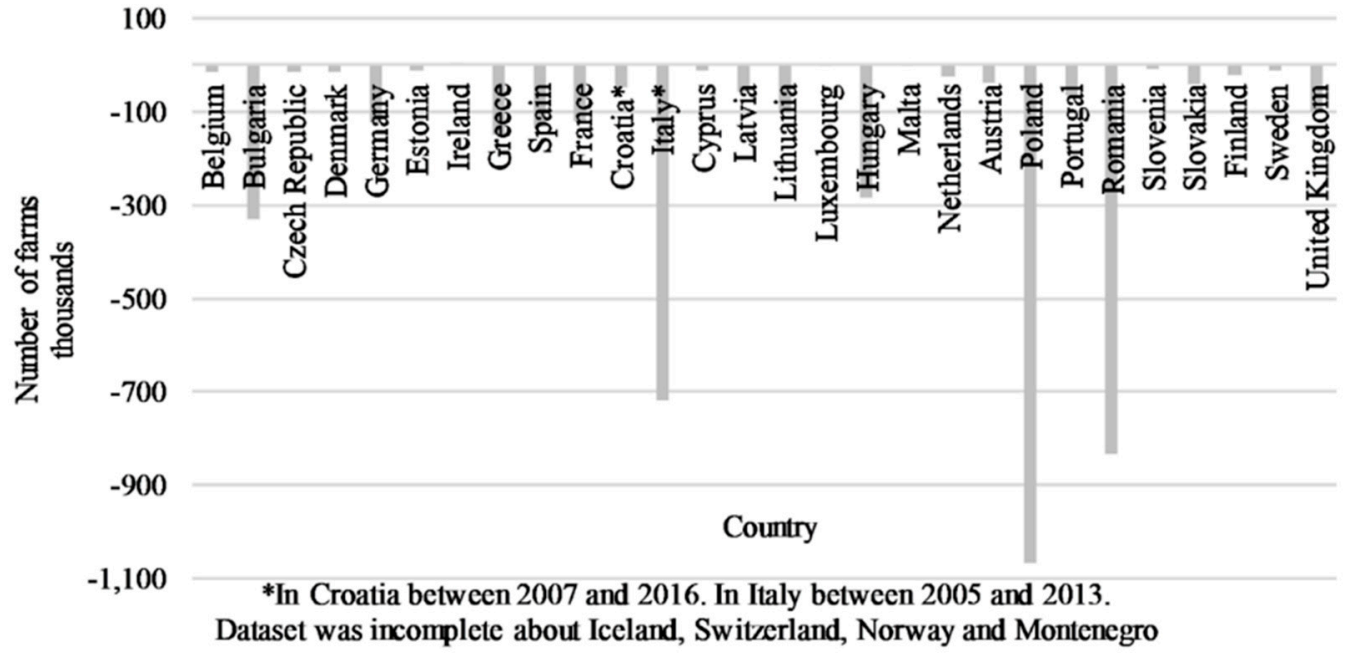

Figure 3. Change in the number of farms in Europe between 2005 and 2016 (Eurostat).

The average growth of agricultural land area per farm between 2005 and 2016 in Europe is 4.8 ha. The biggest growth in agricultural land use per farm has occurred in Slovakia (46.2 ha) and in the Czech Republic (46.0 ha) (Figure 4). In Estonia, the growth of agricultural land use per farm has been also relatively large (29.7 ha) compared to other countries in Europe. Cyprus is the only country where the average utilised agricultural area per farm has decreased slightly (-0.2 ha).

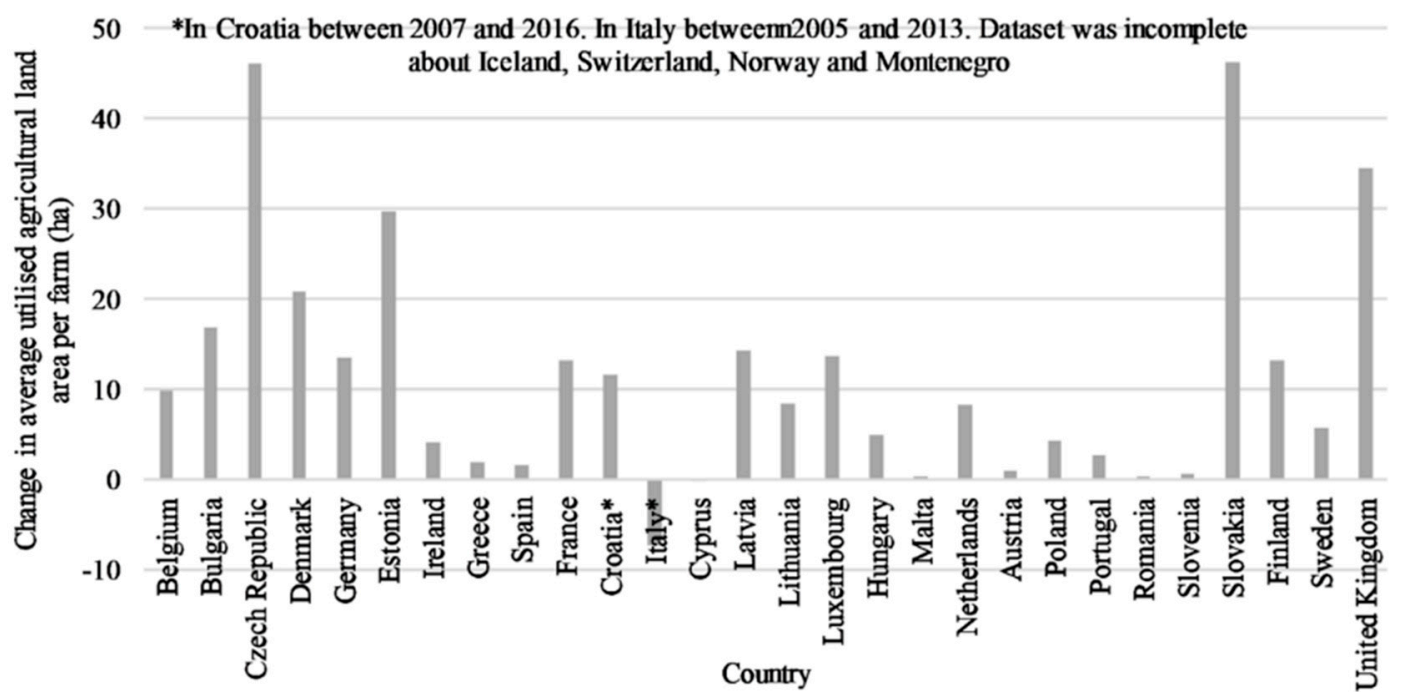

Figure 4. Change in average utilised agricultural land area (ha) per farm between 2005 and 2016 (Eurostat).

While agricultural land use has changed in Europe, the utilised agricultural areas have changed less, having decreased only $1 \%$ as compared to the years 2005 and 2016. At the same time, the shrinking number of farms is remarkable: 30\% fewer farms as compared with 2005 and 2016. The decrease has been larger in some countries while the average utilised agricultural area per farm has increased in almost all countries.

\subsection{Agricultural Land Use Pattern and Its Changes in Estonia}

Statistics show that the number of agricultural households in Estonia has decreased yearly (Figure 5). In 2001 there were 55,748 agricultural households in Estonia but by 2016 this number had decreased to 16,696, concurrently, the area of utilised agricultural land has remained almost the same. Estonian utilised agricultural land area in 2001 was 871,213 ha and in 2016 it was 995,130 ha (Figure 5). 


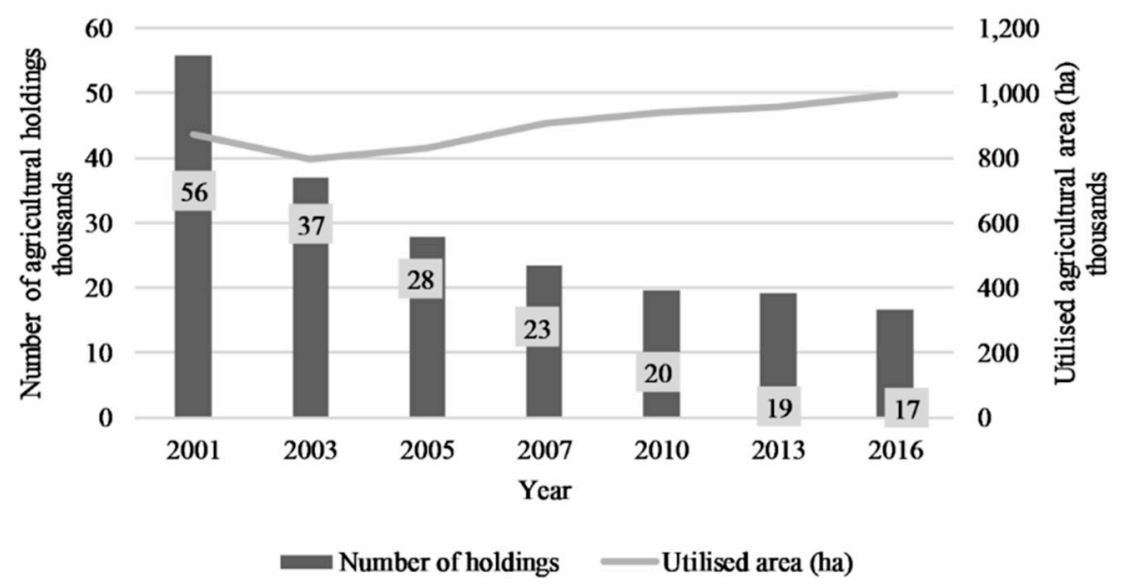

Figure 5. The number of agricultural households and agricultural land area in Estonia between 2001 and 2016 (Statistics Estonia).

The decrease in the number of households and almost constant agricultural land area shows that average land use per agricultural household in Estonia has increased (Figure 6). In 2001 the area of agricultural land use per household was 16 ha but by 2016 it had grown to 60 ha. The average agricultural land-use area per user has grown yearly 2 to 10 ha per year.

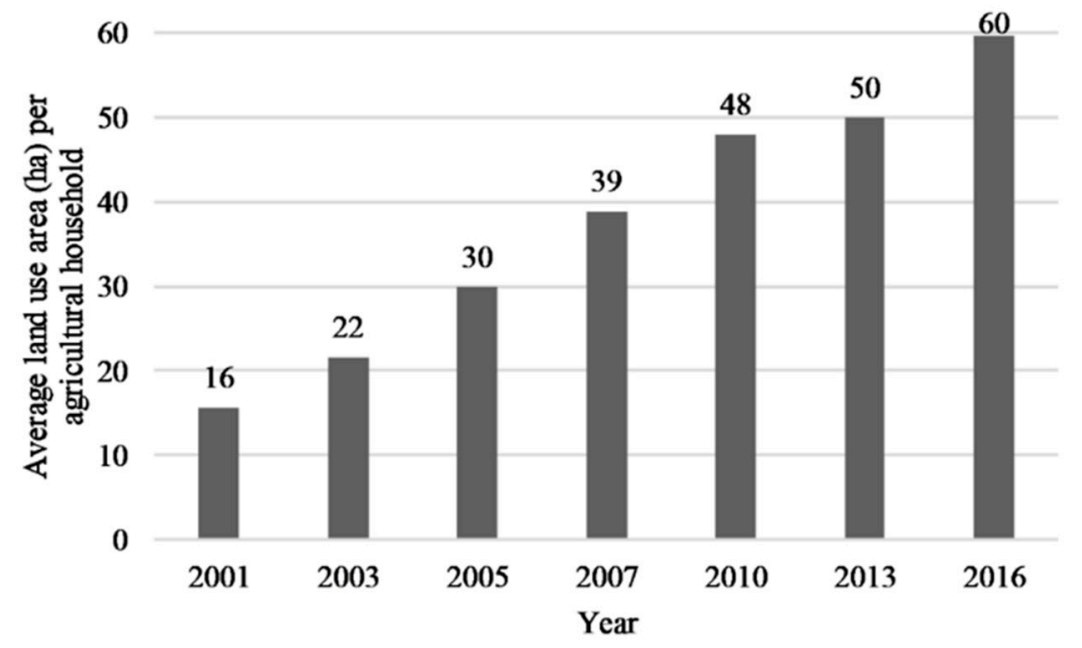

Figure 6. Average land use (ha) per agricultural household in Estonia between 2001 and 2016 (Statistics Estonia).

In 2001 the corporate bodies used 327,788 ha which was 38\% of all agricultural land (Figure 7). While self-employed workers used 543,426 ha of all agricultural land, corporate bodies used 215,638 ha less. By 2016, the situation has changed a lot. Corporate bodies used 645,598 ha $-65 \%$ of agricultural land (ha). At the same time, self-employed workers used 349,505 ha, which is 193,921 ha less than 2001 and 296,093 ha less than corporate bodies in 2016. 


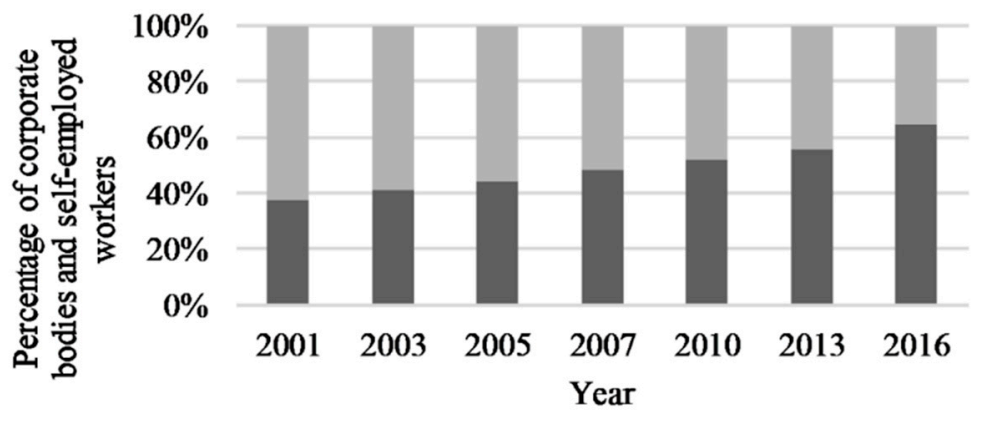

— Corporate body $\quad$ Self-employed worker

Figure 7. Percentage of corporate bodies and self-employed workers in Estonian agriculture between 2001 and 2016 according to the agricultural area (ha) used by agricultural producers (Statistics Estonia).

For a deeper understanding of the changes in the agricultural land use and users sector, the case study based on the ARIB data was undertaken. It is a more comprehensive study that covered all agricultural producers land holdings registered in the ARIB which applied for support from the EU. The data used was from 2011 and 2016. According to ARIB data agricultural land use area has grown 11\% and the number of land users has dropped 5\% in Estonia between 2011 and 2016. Table 1 presents the data for the land users, which were divided into groups according to the size (area) of their landholdings.

Table 1. Data for land users groups that form according to the area of land users land holdings for the years 2011 and 2016 (ARIB).

\begin{tabular}{ccccc}
\hline \multirow{2}{*}{ Groups ha } & \multicolumn{2}{c}{$\mathbf{2 0 1 1}$} & \multicolumn{2}{c}{$\mathbf{2 0 1 6}$} \\
\cline { 2 - 5 } & Number & Area (ha) & Number & Area (ha) \\
\hline$<2$ & 1475 & 2140 & 1355 & 2026 \\
\hline $2-<40$ & 11,654 & 132,888 & 10,767 & 121,960 \\
\hline $40-<100$ & 1460 & 91,563 & 1481 & 93,093 \\
\hline $100-<400$ & 1174 & 225,708 & 1317 & 260,956 \\
\hline $400-<1000$ & 337 & 207,844 & 390 & 237,670 \\
\hline$>1000$ & 126 & 216,893 & 146 & 252,110 \\
\hline Total & 16,226 & 877,036 & 15,456 & 967,816 \\
\hline
\end{tabular}

Comparing the years 2011 and 2016, the number and the area of these land users decreased in two smaller land users' ( $0-2$ ha, $2-<40$ ha) groups and increased in the four following $(40-<100$ ha, $100-<400 \mathrm{ha}, 400-<1000$ ha and $>1000 \mathrm{ha}$ ) groups (see Table 1). Analysis of land users according to the area of their landholdings in size groups $0-<2$ ha, $2-<40$ ha, $40-<100$ ha, $100-<400$ ha, $400-<1000$ ha and $>1000$ ha shows that between 2011 and 2016, agricultural land area used by land users in size groups $100-<400$ and that $>1000$ has grown the most. Agricultural land area used by land users in size groups $0-<2$ and $2-<40$ has decreased and the agricultural land area used by size group $40-<100$ has remained almost the same.

There are 536 agricultural land users in Estonia with land holdings over 400 ha. They are using 489,780 ha or $51 \%$ of the agricultural land utilised in 2016 in Estonia. In 2011, there were 463 agricultural land users with land holdings over 400 ha. They used 424,736 ha or $48 \%$ of the totally-used agricultural area in 2011.

The agricultural land area used by larger land users has grown while the smaller ones have decreased (Figure 8 a). The number of households in size groups $0-<2$ ha and $2-<40$ ha has decreased 
(Figure 8b). In 2011, there were 1,475 agricultural users in size group $0-<2$ ha using 2,139.72 ha of agricultural land. In size group $2-<40$ ha there were 11,654 agricultural land users using 132,888.41 ha. In 2016, there were 120 fewer land users in size group $0-<2$ ha using 813,24 ha less land. In size group $2-<40$ ha there were 887 fewer users, they were using 10,928.15 ha less land than in 2011.
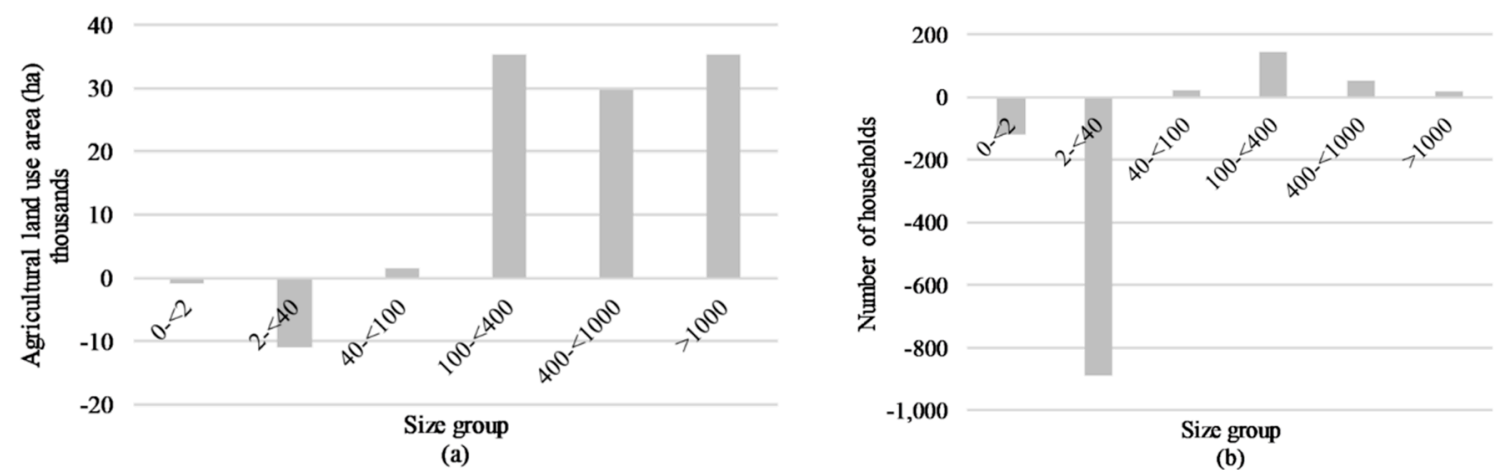

Figure 8. (a) Difference in the area (ha) of agricultural land use, (b) Difference in the number of agricultural households in size groups between 2011 and 2016 (ARIB).

Households in size groups $40-<100$ ha, $100-<400$ ha, $400-<1000$ ha and $>1000$ have grown in number. In 2011, there were 337 land users in size group 400-<1000 ha and they were using 207,843.80 ha of agricultural land. In size group $>1000$ ha, 126 land users were using 216,892.61 ha. By the year 2016, there were 53 more users in size group $400-<1000$ ha and 20 more in size group $>1000$ ha. Agricultural land-use area had grown $29,826.53$ ha in size group $400-<1000$ ha and $35,217.66$ ha in size group $>1000$ ha.

In 2016, there were 257 corporate bodies and 1098 self-employed workers in size group $0-<2$ ha (Figure 9). In size group $2-<40$ ha there were 4,319 corporate bodies and 6,448 self-employed workers. In these two size groups, self-employed workers form the majority. In size groups $400-<1000$ ha and $>1000$ ha there are no self-employed workers. In size group $400-<1000$ ha there are 390 corporate bodies in size group $>1000$ ha there are 146 corporate bodies.

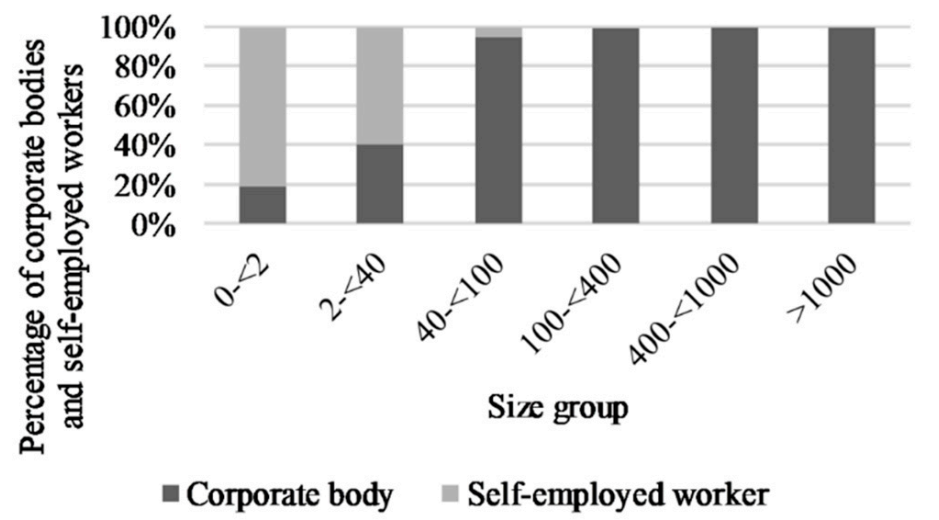

Figure 9. Percentage of corporate bodies and self-employed workers in size groups in 2016 (ARIB).

In 2016 the number of users in size group $0-<2$ ha forms $8.8 \%$ of the total number of agricultural land users in Estonia (Figure 10a) using $0.2 \%$ of the total land use (Figure 10b). The number of land users in size group $2-<40$ ha amounts to $69.7 \%$ of the total number of land users in Estonia using $12.6 \%$ of total land use. Concurrently, the number of agricultural land users in size group 400-<1000 ha accounts for $2.5 \%$ of the total number, using $24.6 \%$ of total land use in Estonia. The number of agricultural land users in size group $>1000$ ha accounts for $0.9 \%$ of the total households, using land $26 \%$ of total land use in Estonia. 


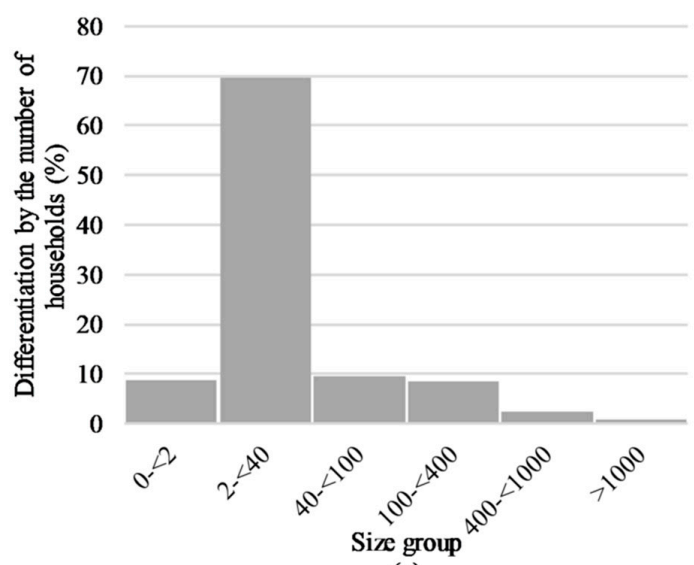

(a)

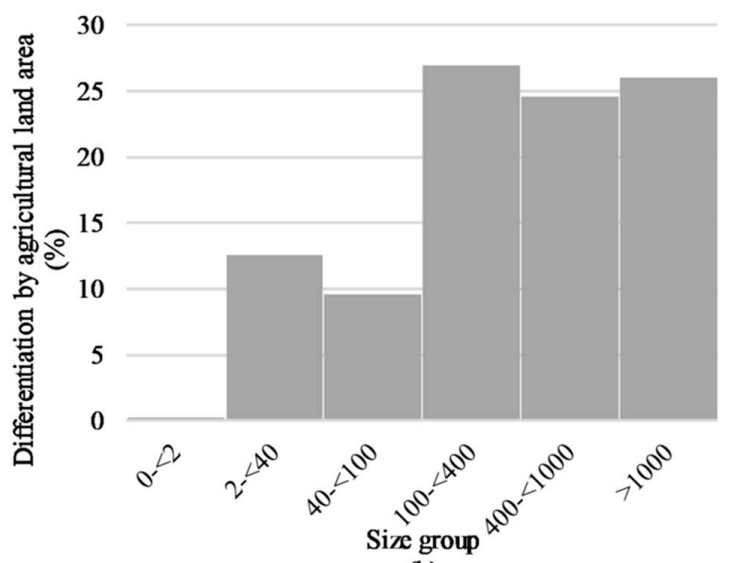

(b)

Figure 10. (a) Differentiation of size groups by the number of households, (b) Differentiation of size groups by agricultural land area in 2016 (ARIB).

\section{Discussion}

The resulting changes in the utilized agricultural area in Europe (Figure 2) are diverse, increasing as well as decreasing in many European countries. A possible direction for this indicator needs future studies. However, it is to be expected that in some countries, agricultural land use has been transformed into other uses. For example, the Czech Republic and Poland have decreased the utilized agricultural land area and the studies $[38,39]$ confirm that changes of agricultural land use to another use, for example for urban needs (dwellings, infrastructure objects, businesses, commercial and retail areas) is problematical. The number of farms in Europe has decreased in all countries (Figure 3) except for Ireland. The average utilized agricultural land area (ha) per farm increased in almost all countries except Italy and Cyprus (Figure 4). That means that despite a decrease in a utilized agricultural area in some countries (Czech Republic, Germany, Poland) there was an even greater decrease in the number of farms, so that average utilized agricultural land area (ha) per farm has actually increased.

The Estonian case presented here that the area of utilized agricultural land has remained almost the same or has increased slightly (Figure 5). The number of landholdings decreased nearly 3 times within 15 years (Figure 5) while the area of agricultural land use per household increased almost 4 times (Figure 6). While average land use per agricultural household in Estonia has increased, the agricultural land in Estonia has become increasingly concentrated into the hands of corporate bodies (Figure 7). Corporate owners held approximately two times more hectares of land in 2016 compared with the year 2001. At the same time, agricultural land used by self-employed workers is decreasing. It suggests that corporate bodies are growing at the expense of agricultural land used by self-employed workers, the reasons for that need further studies.

The deeper case study with the Estonian AIRB data affirms the previous data that the total number of land users has decreased while the utilized agricultural area increased. The total number of agricultural households in Estonia has dropped (Figure 5) and households that have closed their businesses are mostly in size groups $0-<2$ ha and $2-<40$ ha (Figure 8 b). The biggest growth in the number of households between 2011 and 2016 appears in size group 100-<400 ha. The number of self-employed workers in Estonian agriculture has decreased while there has been a growth in corporate bodies (Figure 7). At the same time, there has also been a growth in agricultural household number in size groups over 40 ha (Figure 8). In 2016, most of the self-employed workers are using land in size groups $0-<2$ ha and $2-<40$ ha while corporate bodies form the majority in size groups over 40 ha (Figure 9). There are also some self-employed workers that use agricultural land in size group $40-<100$ ha and a few in $100-<400$ ha. Land users in size groups over 400 ha are mostly corporate bodies. 
The data presents the changes that happened in the agricultural land use and land users sector in Estonia. These changes have taken place within a short time period, only fifteen years (2011-2016). The agricultural land has steadily been concentrated and, at the same time, more land users are corporate bodies. Additionally, it can be firmly stated, according to this study, that while the number of small land users has decreased, the number of larger land users has increased.

Scientists and official documents [6,8-13] have presented the case for smaller vs. larger agricultural producers: smaller farms perform essential tasks in rural society. However, it is also shown that smaller producers are under greater economic pressure. They often need support from the state [3,8]. If this issue is developed only under free-market rules, then the small agricultural producers will shut down their activity. The people who were engaged in small production remain without income and the state must pay the subsistence allowance. The other alternative is for farm labourers to move to find work-normally to the city or towns.

It is important to think beyond the land-use issue to the ownership issue as well. Will the changes in land use pattern bring together changes in the land ownership pattern? This paper addresses the changes in agricultural land use looking at the size of landholdings. It did not distinguish between land that is owned or leased by agricultural producers. It could be that bigger landholdings bring together a concentration of land ownership as well. Agricultural land users get subsidies from the EU. Land users which have bigger holdings receive larger subsidies that enable them to acquire land plots, as is pointed out in documents compiled by the European Economic and Social Committee [8] and requested by the European Parliament's Committee on Agriculture and Rural Development [7].

The question is, is there a need for regulations about land use and/or ownership? Some countries limit land ownership. For example, it is possible to own 500 ha of land in Lithuania and 300 hectares in Hungary [34,40]. Limits for land ownership or use are absent in Estonia. It is theoretically possible for a person with enough money to acquire as much land as is available on the market. The largest land user in Estonia consists of more than 5000 ha of agricultural land, while 146 owners use more than 1000 ha in 2016. The number of such large land users is increasing-it was 126 in 2011, their number in five to ten years is not predictable.

The instructions issued during the Soviet period assigned the optimal agricultural land area for kolkhozes and sovkhozes: 4500-6500 ha agricultural land for kolkhozes or sovkhozes [23,24]. The larger land user in Estonia used the optimal amount of agricultural land (5523 ha) according to these instructions. However, compared to previous use, the kolkhozes or sovkhozes land use in the Soviet period was more compact compared to the current agricultural producers' landholdings. The land reform implementation resulted in land fragmentation, as the previous kolkhozes and sovkhozes were divided among many private owners [25]. Recent agricultural producers must acquire land plots from the land market, thus land holdings are scattered [33]. The area of landholding is comparable or even higher than in the eastern EU member states that, after land reform, became corporate farms [9,30] but the landholdings are more scattered. It means that current land users need more agricultural land for affordable production to compensate for the costs of plot fragmentation. As a result, landholdings will exceed the area that had been used previously by kolhozes and sovkhozes.

Questions about the scale and equitable arrangement of future agricultural land ownership remain. There were two major land reforms in Estonia (1918 and 1991) the purpose of which was to share land holdings between farm owners (mostly German in 1918) and those Estonians who worked the land. Similar examples can be found elsewhere. Now, however, the advent of much larger-scale production, though economically more efficient, also means the concentration of ownership into fewer hands at the expense of small landholders. The resulting imbalance and related societal disruption to rural life and development raise issues that may need to be addressed.

A recent example is from Scotland, where the Government declares: “We are improving Scotland's system of land ownership, use, rights and responsibilities, so that our land may contribute to a fair and just society while balancing public and private interests." [41]. They are undertaking land reform, 
as land ownership is in the hands of a very small number of persons, not the best circumstances for society and rural development.

Estonia needs policy direction and regulations for the agricultural land market that help to mitigate the impact of land concentration in rural areas in the long run, similar to several other European countries [34]. The direction of the policy and extent of the area of land use or ownership is a matter for further research and even debate, to determine appropriate regulations and possible limitations to land areas, e.g. to 300, 500, 1000 or even more hectares.

\section{Conclusions}

The study presents the changes - both increase and decrease - in the utilized agricultural land use in Europe and Estonia. The number of farms decreased while the average utilized agricultural land area (ha) per farm increased in almost all countries in Europe. The decreasing number of agricultural households and almost constant agricultural land area in Estonia shows that average land use per agricultural household has increased. Deeper analyses show that agricultural land in Estonia has become increasingly concentrated into the hands of corporate bodies, that growth has come at the expense of agricultural land used by self-employed workers. These changes have taken place within a short time period and may have been a result of notable change in land relations, after implementation of the post-Soviet land reform. Accordingly, conditions in the agricultural sector should stabilize and such extensive changes should not be the norm in the future.

This paper's aim is to discuss changes in the agricultural sector from the aspect of land use and encourage scientific discussion about the effect of the resulting changes in rural areas. For the discussion to be productive, it needs additional data about the situation in EU countries. As demonstrated, the statistical databases Eurostat and FAOSTAT can provide a range of relevant information in various countries. As the ongoing process of land concentration continues, these changes must be studied more, as there are diverse drivers causing changes in the agricultural sector. Further study must focus on the need for the policy direction and regulations that can mitigate the potential threats that can occur with the land concentration threatening the rural areas. For broad-based statements, input from researchers in different fields is essential. The land holdings should be suitable for necessary and sufficient agricultural production at affordable costs, acceptable to local societies, while also supporting sustainable development. Definitely, the issue is complex. Appropriate solutions cannot arise without further attention.

Author Contributions: Conceptualization, E.J. and M.R.; methodology, E.J. and M.R.; formal analysis, M.R.; investigation, E.J. and M.R.; resources, E.J.; data curation, M.R.; writing-original draft preparation, E.J. and M.R.; writing-review and editing, E.J.; visualization, M.R.; supervision, E.J.; project administration, E.J. All authors have read and agreed to the published version of the manuscript.

Funding: This research received no external funding.

Acknowledgments: We would like to thank four reviewers for their helpful comments.

Conflicts of Interest: The authors declare no conflict of interest.

\section{References}

1. Alexander, E. Land-property markets and planning: A special case. Land Use Policy 2014, 41, 533-540. [CrossRef]

2. Azadi, H.; Houshyar, E.; Zarafshani, K.; Hosseininia, G.; Witlox, F. Agricultural outsourcing: A two-headed coin? Glob. Planet. Chang. 2013, 100, 20-27. [CrossRef]

3. Eurostat. Archive: Small and Large Farms in the EU-Statistics from the Farm Structure Survey. Statistics Explained; Eurostat. 2016. Available online: https://ec.europa.eu/eurostat/statistics-explained/index.php? title=Archive:Small_and_large_farms_in_the_EU_-_statistics_from_the_farm_structure_survey (accessed on 20 December 2019). 
4. Franco, J.; Borras, S.M., Jr. Land Concentration, Land Grabbing and People's Struggles in Europe; Transnational Institute: Amsterdam, The Netherlands, 2013. Available online: https:/www.tni.org/files/download/land_ in_europe-jun2013.pdf (accessed on 5 November 2019).

5. Lowder, S.K.; Skoet, J.; Raney, T. The Number, Size, and Distribution of Farms, Smallholder Farms, and Family Farms Worldwide. World Dev. 2016, 87, 16-29. [CrossRef]

6. European Parliament. The State of Play of Farmland Concentration in the EU: How to Facilitate the Access to Land for Farmers. European Parliament. 2017. Available online: https://www.europarl.europa.eu/doceo/document/ A-8-2017-0119_EN.pdf?redirect (accessed on 1 December 2019).

7. Kay, S.; Peuch, J.; Franco, J. Extent of Farmland Grabbing in the EU. European Parliament. 2015. Available online: https://www.europarl.europa.eu/RegData/etudes/STUD/2015/540369/IPOL_STU(2015)540369_EN. pdf (accessed on 5 January 2020).

8. Land Grabbing - a Warring for Europe and a Threat to Family Farming; European Economic and Social Committee: Bruxelles, Belgium, 2015. Available online: https://www.eesc.europa.eu/en/our-work/opinions-informationreports/opinions/land-grabbing-europefamily-farming (accessed on 1 December 2019).

9. Eurostat. Agriculture Statistics_Family Farming in the EU. Statistics Explained. 2018. Available online: https://ec.europa.eu/eurostat/statistics-explained/pdfscache/38078.pdf (accessed on 5 November 2019).

10. Grubbström, A.; Sooväli-Sepping, H. Estonian family farms in transition: A study of intangible assets and gender issues in generational succession. J. Hist. Geogr. 2012, 38, 329-339. [CrossRef]

11. Guiomar, N.; Godinho, S.; Pinto-Correia, T.; Almeida, M.; Bartolini, F.; Bezák, P.; Biró, M.; Bjørkhaug, H.; Bojnec, Š.; Brunori, G.; et al. Typology and distribution of small farms in Europe: Towards a better picture. Land Use Policy 2018, 75, 784-798. [CrossRef]

12. McDonagh, J.; Farrell, M.; Conway, S. The Role of Small-scale Farms and Food Security. In Sustainability Challenges in the Agrofood Sector; Wiley: Hoboken, NJ, USA, 2017; pp. 33-47.

13. Shucksmith, M.; Rønningen, K. The Uplands after neoliberalism?-The role of the small farm in rural sustainability. J. Rural. Stud. 2011, 27, 275-287.

14. Davidova, S.; Thomson, K. Family Farming in Europe: Challenges and Prospects. 2014. Available online: https: //www.europarl.europa.eu/RegData/etudes/note/join/2014/529047/IPOL-AGRI_NT(2014)529047_EN.pdf (accessed on 1 December 2019).

15. Looga, J.; Jürgenson, E.; Sikk, K.; Matveev, E.; Maasikamäe, S. Land fragmentation and other determinants of agricultural farm productivity: The case of Estonia. Land Use Policy 2018, 79, 285-292. [CrossRef]

16. Csaki, C.; Lerman, Z. Structural Change in the Farming Sectors in Central and Eastern Europe: Lessons for the EU Accession; World Bank: Washington, DC, USA, 2000; p. 272. Available online: http://documents. worldbank.org/curated/en/267151468776098706/Structural-change-in-the-farming-sectors-in-Central-andEastern-Europe-lessons-for-EU-accession-Second-World-Bank-FAO-Workshop-June-27-29-1999 (accessed on 5 January 2020).

17. Kivistik, J. Agraarstruktuuri muutustest Eesti Vabariigis. In EPMÜ teadustööde kogumik; Infotrükk: Tallinn, Estonian, 1997; pp. 44-47.

18. Lillak, R. Eesti põllumajanduse ajalugu; Trükikoda Trükipunkt: Tartu, Estonian, 2003; p. 260.

19. Roosenberg, T. Künnivaod. Uurimusi Eesti 18.-20. sajandi agraarajaloost; Tartu Ülikooli Kirjastus: Tartu, 2013; ISBN 978-9949-32-226-8. Available online: https://www.tyk.ee/admin/upload/files/raamatud/1366367626.pdf (accessed on 5 January 2020). (In Estonian)

20. Virma, F. Maasuhted, maakasutus ja maakorraldus Eestis; OÜ Halo Kirjastus: Tallinn, Estonian, 2004; p. 339, ISBN 9985-9553-3-1. (In Estonian)

21. Sirendi, A. Eesti Póllumajandus XX sajandil (2. osa); Eesti Vabariigi Põllumajandusministeerium: Tallinn, Estonian, 2007; p. 328, ISBN 9789949136483. (In Estonian)

22. Mander, Ü.; Palang, H. Changes of Landscape Structure in Esonia during the Soviet Period. GeoJournal 1994, 33, 45-54.

23. Kasepalu, A. Mis peremees jätab, Selle Mets võtab; Eesti teaduste Akadeemia Majanduse Instituut: Tallinn, Estonian, 1991; p. 129. (In Estonian)

24. Eesti NSV Teaduste Akadeemia Majanduse Instituut. Põllumajandusökonoomika küsimusi. 4 osa; Eesti Riiklik Kirjastus: Tallinn, Estonian, 1964; p. 171. (In Estonian)

25. Jürgenson, E. Land reform, land fragmentation and perspectives for future land consolidation in Estonia. Land Use Policy 2016, 57, 34-43. [CrossRef] 
26. Adams, M. Breaking Ground: Development Aid for Land Reform; Oversea Development Institute: London, UK, 2000; ISBN 085003500 7. Available online: https://www.odi.org/sites/odi.org.uk/files/odi-assets/publicationsopinion-files/8124.pdf (accessed on 5 January 2020).

27. Swinnen, J.F.M. The political economy of land reform choices in Central and Eastern Europe. Econ. Transit. 1999, 7, 637-664. [CrossRef]

28. Swinnen, J.F.M.; Mathijs, E. Agricultural privatisation, land reform and farm restructuring in Central and Eastern Europe: A comparative analysis. In Agricultural Privatisation, Land Reform and Farm Restructuring in Central and Eastern Europe; Swinnen, J.F.M., Buckwell, A., Mathijs, E., Eds.; Routledge: London, UK, 1997; pp. 333-337. ISBN 1-85972-648-8.

29. Hartvigsen, M. Experiences with Land consolidation and Land banking in Central and Eastern Europe after 1989; Land Tenure; FAO: Rome, Italy, 2015; pp. 1-128. Available online: http://www.fao.org/3/a-i4352e.pdf (accessed on 5 January 2020).

30. Hartvigsen, M. Land reform and land fragmentation in Central and Eastern Europe. Land Use Policy 2014, 36, 330-341. [CrossRef]

31. Van Dijk, T. Scenarios of Central European land fragmentation. Land Use Policy 2003, 20, 149-158. [CrossRef]

32. Van Dijk, T. Dealing with Central European land fragmentation: A Critical Assessment on the Use of Western European Instruments; Eubron Delft: Delft, The Netherlands, 2003; ISBN 90-5166-996-8. Available online: https://library.wur.nl/WebQuery/wurpubs/346204 (accessed on 5 January 2020).

33. Maasikamäe, S.; Jürgenson, E.; Sikk, K. The Rearrangement of Leasehold Agreements as an Alternative to Land Consolidation; Kadaster International: Apeldoorn, The Netherlands, 2016; pp. 207-215. Available online: https://www.oicrf.org/documents/40950/43224/The+Rearrangement+of+the+Leasehold+Agreements+ as+an+Alternative+to+the+Land+Consolidation\%281\%29.pdf/6a78bea7-e376-3b40-f4dc-b736ab35ebf2 (accessed on 1 December 2019).

34. AEIAR. Status of Agricultural Land Market Regulation in Europe. AEIAR. 2016. Available online: http:// www.aeiar.eu/wp-content/uploads/2016/04/Land-market-regulation_policies-and-instruments-v-def2.pdf (accessed on 7 November 2019).

35. Van Vliet, J.; De Groot, H.L.; Rietveld, P.; Verburg, P.H. Manifestations and underlying drivers of agricultural land use change in Europe. Landsc. Urban Plan. 2015, 133, 24-36. [CrossRef]

36. European Coordination Via Campensina ECVC Toolkit on Land Grabbing and Access to Land in Europe 2017. Available online: http://www.eurovia.org/wp-content/uploads/2017/04/EN_ECVC-Land-Kit.pdf (accessed on 1 December 2019).

37. Valdvee, E.; Klaus, A. Agricultural Holdings in the Baltic and Nordic Countries. In Quaterly Bulletin of Statistics Estonia; Statistics Estonia; 2009; pp. 110-115, ISBN 1736-7921. Available online: https://www.stat.ee/ valjaanne-2009_eesti-statistika-kvartalikiri-1-09 (accessed on 5 November 2019).

38. Václavík, T.; Rogan, J. Identifying Trends in Land Use/Land Cover Changes in the Context of Post-Socialist Transformation in Central Europe: A Case Study of the Greater Olomouc Region, Czech Republic. GISci. Remote Sens. 2009, 46, 54-76. [CrossRef]

39. Busko, M.; Szafrańska, B. Analysis of Changes in Land Use Patterns Pursuant to the Conversion of Agricultural Land to Non-Agricultural Use in the Context of the Sustainable Development of the Malopolska Region. Sustainability 2018, 10, 136. [CrossRef]

40. Ciaian, P.; Kancs, D.; Swinnen, J.F.M. EU Land Marets and the Common Agricultural Policy; 2010; ISBN 978-92-9079-963-4. Available online: https://papers.ssrn.com/sol3/papers.cfm?abstract_id=1604452 (accessed on 5 January 2020).

41. Scottish Government Land Reform. Available online: https://www.gov.scot/policies/land-reform/ (accessed on 7 December 2019).

(C) 2020 by the authors. Licensee MDPI, Basel, Switzerland. This article is an open access article distributed under the terms and conditions of the Creative Commons Attribution (CC BY) license (http://creativecommons.org/licenses/by/4.0/). 